\title{
РАСПРОСТРАНЕНИЕ И СОСТОЯНИЕ ОХРАНЯЕМОГО ЛИШАЙНИКА БРИОРИЯ НАДВОРНИКА (ВRYORІА NADVORNIKIANA (GYELN.) BRODO ET D. HAWKSW.) В ЛЕСНЫX СООБЩЕСТВАХ ПЕТРОЗАВОДСКОГО ГОРОДСКОГО ОКРУГА
}

\author{
А. А. Фенько', В. Н. Тарасова ${ }^{2}$ \\ 1 Институт биологии Карельского научного центра РАН \\ 2 Петрозаводский государственный университет
}

\begin{abstract}
Исследования состояния ценопопуляций охраняемого вида лишайника Bryoria nadvornikiana выполнены впервые для России, в лесных сообществах Петрозаводского городского округа, двумя методами (маршрутным и методом пробных площадей). В результате исследований было зарегистрировано 555 талломов, произрастающих на 195 деревьях ели. У каждого таллома измеряли длину, ширину и высоту произрастания над землей. Установлено, что в лесных сообществах города бриория чаще всего встречается в ельниках черничных влажных (46\%). Максимальное число талломов (43 \%) обнаружено на молодых деревьях ели возрастом 40-54 года, высотой 4-6 м, с диаметром ствола 6-10 см. Наиболее благоприятные условия для обитания вида складываются в нижней части кроны. Появление вида в осиновых лесах обусловлено наличием молодых елей, выходящих из состояния подроста, имеющих нижние сухие ветви, пригодные для заселения. С увеличением антропогенной нагрузки число талломов B. nadvornikiana в лесах Петрозаводского городского округа снижается. Состояние популяций бриории в лесных сообществах города в настоящее время можно охарактеризовать как нормальное.
\end{abstract}

Ключе в ы е сло в а: Bryoria nadvornikiana; популяция; экология; городская среда; таежные экосистемы.

\section{A. A. Fenko, V. N. Tarasova. DISTRIBUTION AND CONDITION OF THE PROTECTED LICHEN BRYORIA NADVORNIKIANA (GYELN.) BRODO ET D. HAWKSW. IN FOREST COMMUNITIES IN THE CITY OF PETROZAVODSK}

The condition of the coenopopulations of the protected lichen Bryoria nadvornikiana was studied for the first time in Russia in forest communities of the City of Petrozavodsk using two methods (based on transects and on sample plots). The resultant records include 555 thalli growing on 195 spruce trees. Each thallus was measured for length, width, and elevation above the ground. Among the forest communities of the city, Bryoria most frequently occurred in moist bilberry spruce stands (46\%). The greatest number of thalli (43\%) was found on young spruce trees aged $40-54$ years, 4-6 $\mathrm{m}$ tall, 6-10 cm in diameter. Lower crown offers the most favorable conditions for this species. In aspen stands the species appeared owing to the presence of young spruce trees emerging from the undergrowth, with lower dry branches suitable for colonization. The number of $B$. nadvornikiana thalli in Petrozavodsk urban forests decreases as human pressure builds up. The current state of Bryoria populations in forest communities of the city can be described as normal. 
Keywords: Bryoria nadvornikiana; population; ecology; urban environment; boreal ecosystems.

\section{Введение}

Bryoria nadvornikiana (Gyeln.) Brodo et D. Hawksw. - эпифитный кустистый лишайник семейства Parmeliaceae, внесен в Красные книги стран Северной Европы - Норвегии [Timdal et al., 2010], Финляндии [Rassi et al., 2010], Швеции [Gärdenfors, 2010], а также некоторых регионов Российской Федерации - Республики Карелия [2007], Республики Татарстан [2006], Ленинградской [2000], Псковской [2014] и Рязанской [2011] областей. Бриория Надворника чаще всего обитает на хвойных деревьях в разных типах еловых лесов и в старовозрастных сосняках; реже - на деревьях лиственных пород [Голубкова, 1996]. Вид встречается также на коре сосны, рододендрона, лиственницы, пихты и дуба [Wang et al., 2005]. Характерными отличиями этого вида рода Bryoria являются: свисающий, или чаще торчащий, неравномерно окрашенный двухцветный таллом, с более темным основанием и боковыми колючкообразными выростами на осевых «ветвях» (рис. 1).

На данный момент экология вида изучена недостаточно. Согласно имеющимся литературным данным, бриория Надворника в лесных сообществах провинции Квебек (Канада) является видом, предпочитающим относительно сомкнутый полог леса. Исследование роста бриории показало, что открытость древесного

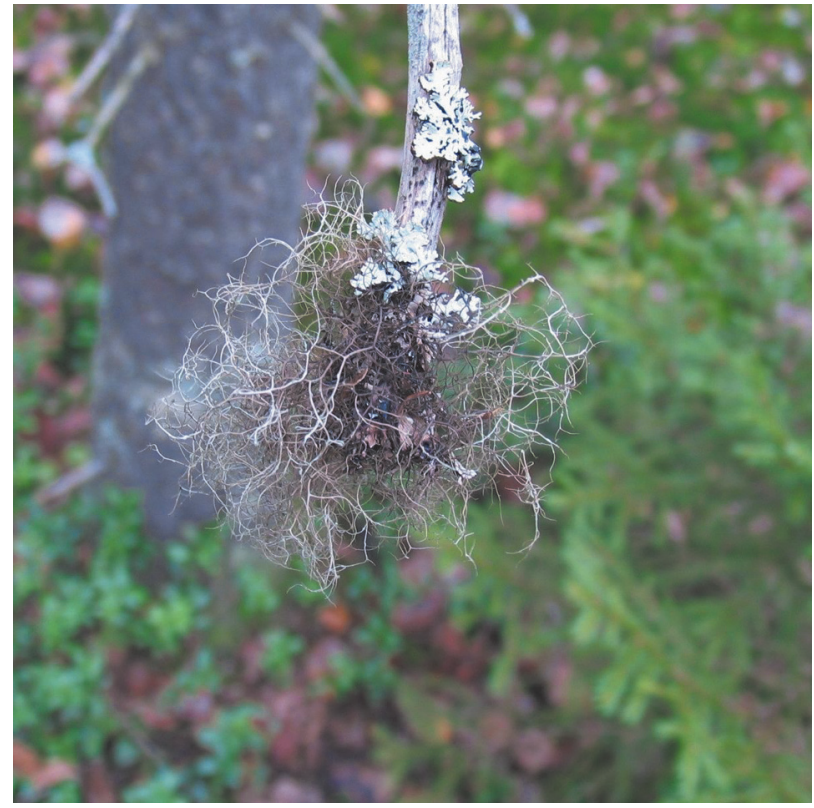

Рис. 1. Бриория Надворника на ветви ели европейской Фото В. Н. Тарасовой полога свыше 40 \% приводит к негативному темпу роста лишайника [Boudreault et al., 2013]. Вид встречается вдоль берегов озер, рек и в других влажных местообитаниях [Kuusinen, 1991; Голубкова, 1996]. Бриория Надворника чувствительна к загрязнению атмосферного воздуха и является индикатором малонарушенных лесных сообществ [Kuusinen, 1991; Signalarter, 2000]. Факторами, угрожающими существованию вида, считаются загрязнение воздуха, сведение лесов (особенно старых заболоченных), строительство дорог, лесные пожары, применение ядохимикатов [Красная книга..., 2000].

В Красную книгу Республики Карелия (2007) вид внесен с категорией охраны 3. Очевидно, что распространение вида в республике в настоящее время изучено недостаточно, поскольку бриория известна только по нескольким находкам, в различных биогеографических провинциях [Фадеева и др., 2007].

Район исследования г. Петрозаводск - крупный промышленный, транспортный и туристический центр Северо-Запада России. Территория Петрозаводского городского округа (ПетрГО) вытянута почти на 25 км вдоль Петрозаводской губы Онежского озера (6150' с. ш., $34^{\circ} 20^{\prime}$ в. д.), занимает площадь около 113,0 км², с численностью населения - 266,2 тыс. чел. [Андросова, 2010]. Естественные экосистемы в пределах ПетрГО занимают значительную площадь ( 6933 га) и представлены в основном коренными лесными формациями - ельниками и сосняками, а также производными лесами, среди которых встречаются осинники, ольшаники и березняки [Волков, 2008]. Для территории ПетрГО известно 330 видов лишайников, в том числе и бриория Надворника [Tarasova et al., 2013, 2015].

Целью настоящей работы было изучение распространения, экологии и состояния вида Bryoria nadvornikiana в лесных сообществах Петрозаводского городского округа.

\section{Материалы и методы}

Сбор материала проводился в летний период 2011-2013 гг. в лесных сообществах ПетрГО. Для изучения экологии вида B. nadvornikiana использованы маршрутный метод и метод пробных площадей. Маршруты разрабатывались на основе космических снимков 


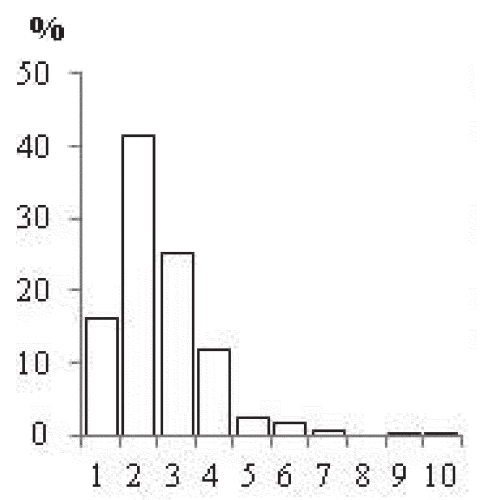

Дппна талломов, мм
$1-9-26$

$2-27-44$

$3-45-62$

$4-63-80$

$5-81-98$

$6-99-116$

$7-117-134$

$8-135-152$

9- $153-170$

$10-171-188$

a

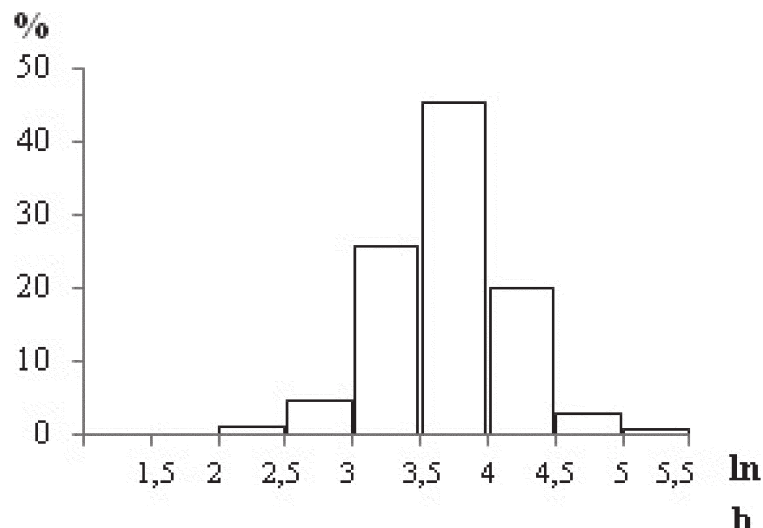

b

Рис. 2. Распределение числа талломов B. nadvornikiana (\%) по длине (а) и по натуральному логарифму длины (b) в растительных сообществах ПетрГО

таким образом, чтобы максимально охватить площадь исследования и различные типы лесных сообществ. В пределах ПетрГО было исследовано пять маршрутов («Древлянка», «Томицы», «Пески», «5-й поселок», ландшафтный заказник «Заозерский») общей протяженностью 38 км. Пробные площади (далее - ПП) размером $50 \times 50$ м закладывались в местах обитания вида в сообществах двух формаций: 9 ПП - в ельниках с разной степенью антропогенной нагрузки (сильно-, средне-, относительно малонарушенные); 6 ПП - в осинниках (молодые осиновые леса с подростом ели; средневозрастные осиновые леса с елью, которая выходит из стадии подроста; смешанные елово-осиновые леса). В месте обитания вида регистрировали характеристики сообщества: тип леса, долю участия ели в древостое, сомкнутость крон деревьев (сквозистомером Ипатова), сумму площадей сечений стволов деревьев (полнотомером Биттерлиха); параметры деревьев: породу, возраст (возрастным буравом), высоту (эклиметром), диаметр ствола дерева на высоте 130 см (сантиметровой лентой); параметры микроусловий: экспозицию ствола дерева (компасом), высоту произрастания над землей (0-200 см). Для каждого образца вида измеряли длину и ширину таллома. Статистическая обработка результатов выполнена на основе однофакторного регрессионного анализа [Ивантер, Коросов, 2011].

\section{Результаты и обсуждение}

В ходе исследований на территории ПетрГО было обнаружено 555 талломов B. nadvornikiana, произрастающих на 195 деревьях ели. Из них 140 талломов (на 62 деревьях) были изучены при помощи маршрутного метода. Остальные 415 талломов выявлены и обследованы на 15 ПП общей площадью 3,75 га: 297 талломов
(99 деревьев) на 9 ПП в ельниках и 118 талломов (37 деревьев) - на 6 ПП в осинниках.

Таким образом, плотность популяции бриории Надворника в растительных сообществах ПетрГО в среднем составляет 3,7 таллома на 1 км маршрута (при изучении маршрутным методом). На 1 гектаре в ельниках в среднем обитает 132 таллома бриории, в осинниках - 78 (при изучении методом пробных площадей).

Согласно литературным данным, таллом бриории Надворника может иметь длину до 20 см [Thell, Moberg, 2011]. На территории ПетрГО длина таллома этого вида варьирует от 9 до 175 мм и в среднем составляет 45 \pm 0,9 мм (рис. 2). Распределение числа образцов вида по длине таллома логнормальное, с левосторонней асимметрией (рис. 2, b). Преобладают талломы длиной 27-44 мм (41\%); талломы длиной более 100 мм встречаются достаточно редко (2,5 \%) (рис. 2, а).

На территории города вид встретился во всех исследуемых районах, с преобладанием в микрорайонах Кукковка и Древлянка (рис. 3).

В результате исследований было установлено, что B. nadvornikiana на территории ПетрГО встречается в лесных сообществах четырех формаций: в ельниках (черничных влажных, черничных свежих, кустарничковых сфагновых), сосняках (черничных свежих), во вторичных лесах - осинниках и березняках разнотравно-черничных (табл. 1). При этом большая часть талломов (68 \%) была обнаружена в ельниках, а именно - ельниках черничных влажных (46 \%), очевидно, ввиду большей встречаемости данного типа леса на территории ПетрГО и наличия здесь подходящего субстрата. В березняках, осинниках и сосняках число талломов снижается в связи с уменьшением доли участия ели в составе древостоя и, соответственно, уменьшением числа субстрата для заселения вида. 


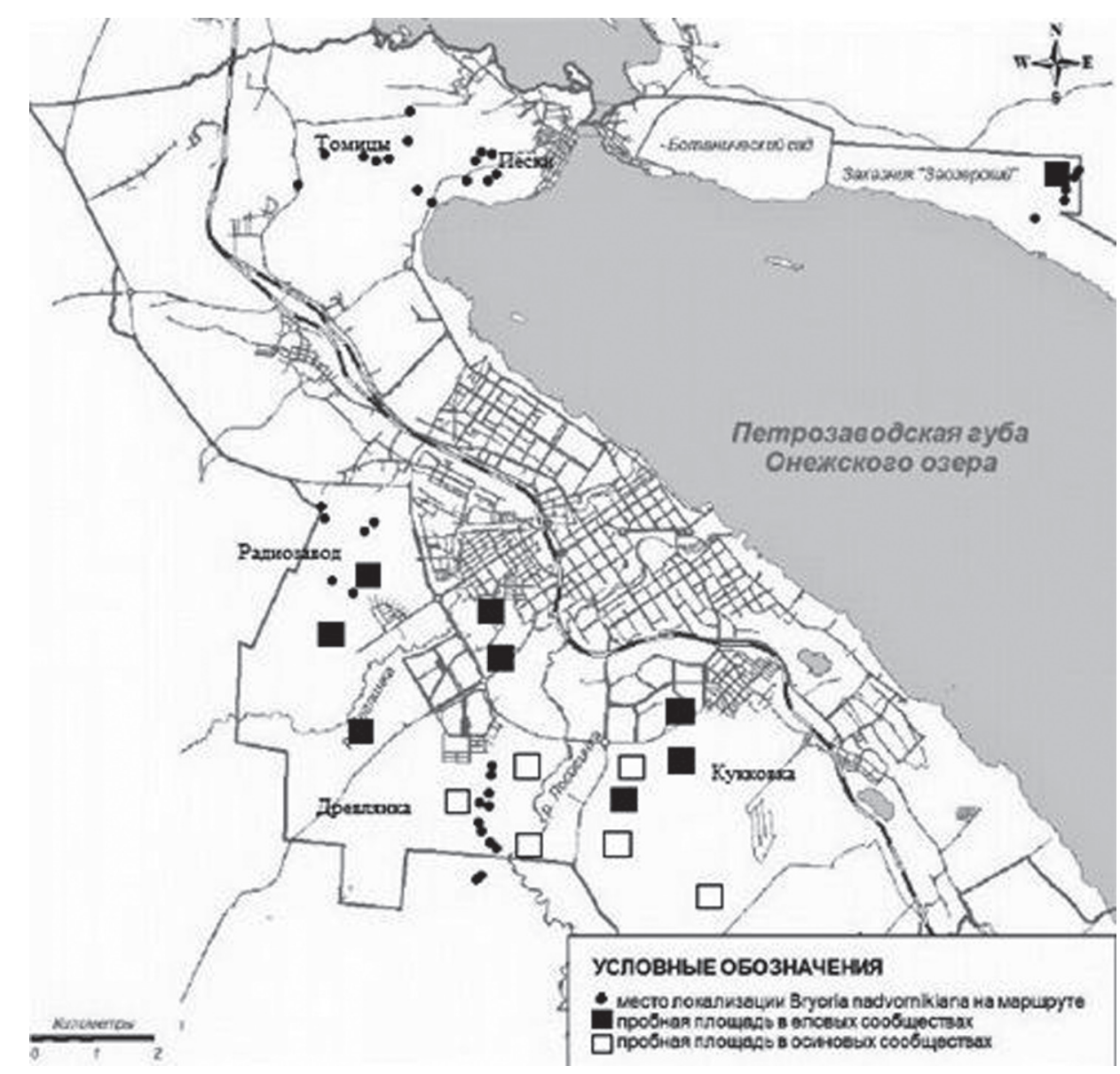

Рис. 3. Распространение В. nadvornikiana в лесных сообществах Петрозаводского городского округа

Бриория Надворника в условиях ПетрГО обитает только на одном типе субстрата - на ветвях ели европейской, не только на живых, но и на сухостойных деревьях. Во всей выборке, полученной как маршрутным, так и площадным методом, на ветвях последних было обнаружено 79 талломов лишайника (27 деревьев). Среднее число талломов на дереве составляет 2,8 .

Установлено, что морфометрические показатели (ширина и длина таллома) B. nadvornikiana не зависят от изученных общих и частных характеристик местообитания, а наиболее информативным показателем является число талломов вида. Так, с увеличением доли участия ели в древостое число талломов лишайника увеличивается (рис. 4). Вероятно, это связано с тем, что ель является основным субстратом для вида.

Вместе с этим взаимосвязь между показателями бриории и таким существенным для нее, согласно литературным данным, параметром, как сомкнутость крон деревьев, в изученной выборке отсутствует. Вероятно, потому что этот показатель в большинстве изученных сообществ варьирует незначительно - от 43 до

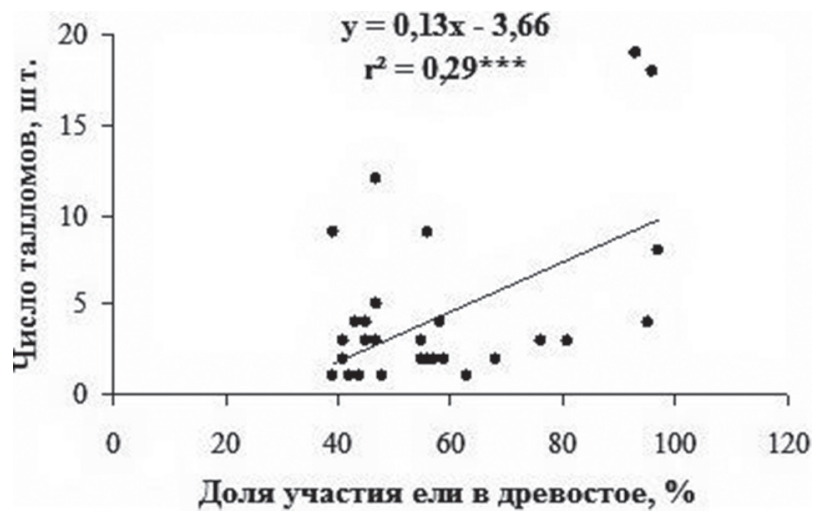

Рис. 4. Число талломов В. nadvornikiana в еловых лесах ПетрГО с разной долей участия ели в древостое

58 \% и находится в пределах ее оптимума [Boudreault et al., 2013]. Только в одном сообществе - ельнике кустарничковом сфагновом - сомкнутость крон составляет $25 \%$, и здесь встретилось всего 8 (1,4\%) талломов лишайника (табл. 1).

Возраст деревьев, на которых обитает B. nadvornikiana в пределах ПетрГО, варьирует от 20 до 125 лет. С увеличением возраста деревьев с 20 до 50 лет число талломов лишайника увеличивается, а после 50 лет - снижается 
Таблица 1. Основные характеристики лесных сообществ, изученных маршрутным методом

\begin{tabular}{|c|c|c|c|c|c|c|c|}
\hline Тип леса & $\begin{array}{c}\text { Число } \\
\text { обследованных } \\
\text { лесных } \\
\text { сообществ } \\
\text { (выделов) }\end{array}$ & $\begin{array}{c}\text { Формула } \\
\text { древостоя }\end{array}$ & $\begin{array}{c}\text { Сумма } \\
\text { площадей } \\
\text { сечения } \\
\text { древостоя, } \\
\text { м²га }^{2}\end{array}$ & $\begin{array}{c}\text { Доля } \\
\text { участия } \\
\text { ели в } \\
\text { древостое, } \\
\%\end{array}$ & $\begin{array}{c}\text { Сомкнутость } \\
\text { крон, } \\
\%\end{array}$ & $\begin{array}{c}\text { Общее } \\
\text { число } \\
\text { талломов, } \\
\text { шт. }\end{array}$ & $\begin{array}{c}\text { Средняя } \\
\text { длина } \\
\text { таллома, } \\
\text { мм }\end{array}$ \\
\hline $\begin{array}{c}\text { Ельник черничный } \\
\text { влажный }\end{array}$ & 11 & 8E 1Б 1OC & 26 & 81 & 58 & 64 & $46 \pm 2,6$ \\
\hline $\begin{array}{c}\text { Ельник черничный } \\
\text { свежий }\end{array}$ & 4 & $\begin{array}{c}5 E 3 C 15 \\
10 C\end{array}$ & 25 & 55 & 47 & 23 & $45 \pm 6,2$ \\
\hline $\begin{array}{c}\text { Ельник } \\
\text { кустарничковый } \\
\text { сфагновый }\end{array}$ & 1 & $9 \mathrm{E} 1 \mathrm{~B}$ & 21 & 95 & 25 & 8 & $55 \pm 9,3$ \\
\hline $\begin{array}{c}\text { Осинник } \\
\text { разнотравно- } \\
\text { черничный }\end{array}$ & 4 & 6OC 3E 1Б & 29 & 36 & 58 & 18 & $45 \pm 3,4$ \\
\hline $\begin{array}{c}\text { Березняк } \\
\text { разнотравно- } \\
\text { черничный }\end{array}$ & 6 & $\begin{array}{c}6 \mathrm{6} 2 \mathrm{E} 1 \mathrm{C} \\
1 \mathrm{CC}\end{array}$ & 25 & 25 & 43 & 22 & $53 \pm 5,4$ \\
\hline $\begin{array}{c}\text { Сосняк черничный } \\
\text { свежий }\end{array}$ & 1 & $6 C 3 E 1 P$ & 23 & 28 & 50 & 5 & $45 \pm 6,1$ \\
\hline
\end{tabular}

Примечание. Здесь и далее в таблицах приняты следующие обозначения: Е - ель, С - сосна, ОС - осина, Б береза, Р - рябина, ОЛ - ольха.

Таблица 2. Основные характеристики лесных сообществ, изученных методом пробных площадей

\begin{tabular}{|c|c|c|c|c|c|c|c|}
\hline $\begin{array}{c}\text { Тип сообщества, } \\
\text { категория }\end{array}$ & $\begin{array}{c}\text { Число } \\
\text { пробных } \\
\text { площадей } \\
50 \times 50 \text { м }\end{array}$ & $\begin{array}{l}\text { Формула } \\
\text { древостоя }\end{array}$ & $\begin{array}{c}\text { Сумма } \\
\text { площадей } \\
\text { сечения } \\
\text { древостоя, } \\
\text { м²га }^{-1}\end{array}$ & \begin{tabular}{|c|} 
Доля \\
участия ели \\
в древостое, \\
$\%$
\end{tabular} & $\begin{array}{c}\text { Сомкнутость } \\
\text { крон, \% }\end{array}$ & $\begin{array}{c}\text { Общее } \\
\text { число } \\
\text { талломов, } \\
\text { шт. }\end{array}$ & $\begin{array}{c}\text { Средняя } \\
\text { длина } \\
\text { таллома, } \\
\text { мм }\end{array}$ \\
\hline $\begin{array}{c}\text { Ельник черничный } \\
\text { свежий, } \\
\text { сильнонарушенный }\end{array}$ & 3 & $9 \mathrm{E} 1 \mathrm{C}$ & 30 & 91 & 62 & 6 & $36 \pm 6,6$ \\
\hline $\begin{array}{c}\text { Ельник черничный } \\
\text { свежий, } \\
\text { средненарушенный }\end{array}$ & 3 & $\begin{array}{c}5 \mathrm{E} 2 \mathrm{OC} 2 \mathrm{C} \\
1 \mathrm{~B}\end{array}$ & 27 & 50 & 55 & 143 & $47 \pm 2,0$ \\
\hline $\begin{array}{c}\text { Ельник черничный } \\
\text { свежий, относительно } \\
\text { малонарушенный }\end{array}$ & 3 & 7E 2OC 15 & 26 & 74 & 61 & 148 & $41 \pm 3,3$ \\
\hline $\begin{array}{l}\text { Осинник разнотравно- } \\
\text { черничный, молодняк }\end{array}$ & 2 & $\begin{array}{c}\text { 5OC 2Б 2Е } \\
1 \text { ОЛ }\end{array}$ & 24 & 17 & 65 & 0 & - \\
\hline $\begin{array}{c}\text { Осинник разнотравно- } \\
\text { черничный, } \\
\text { средневозрастный }\end{array}$ & 2 & 5ОС 3Е 2Б & 25 & 30 & 63 & 104 & $45 \pm 6,2$ \\
\hline $\begin{array}{c}\text { Смешанный } \\
\text { осиново-еловый } \\
\text { лес разнотравно- } \\
\text { черничный }\end{array}$ & 2 & $\begin{array}{c}\text { 4OC 3E 25 } \\
1 \text { CO }\end{array}$ & 27 & 26 & 59 & 14 & $37 \pm 5,5$ \\
\hline
\end{tabular}

(рис. 5). Для таких таксационных показателей деревьев, как высота и диаметр ствола, были получены сходные результаты.

Таким образом, вид B. nadvornikiana начинает заселять ель возрастом 20 лет; максимальное число талломов (43\%) обнаружено на молодых деревьях возрастом 40-54 года, высотой 4-6 м, с диаметром ствола (на 1,3 м) 6-10 см; при дальнейшем увеличении значений таксационных параметров деревьев число талломов снижается. Снижение числа талломов с увеличением изученных характеристик можно объяснить тем, что с возрастом дерева высота нижней части кроны увеличивается, и соответственно, нижние ветви ее оказываются значительно выше, чем у молодых деревьев, что в итоге приводит к уменьшению количества субстрата, пригодного для заселения. Уменьшение числа талломов бриории также связано с тем, что в более высокой кроне снижается количество влаги, а согласно имеющимся данным, вид предпочитает местообитания 


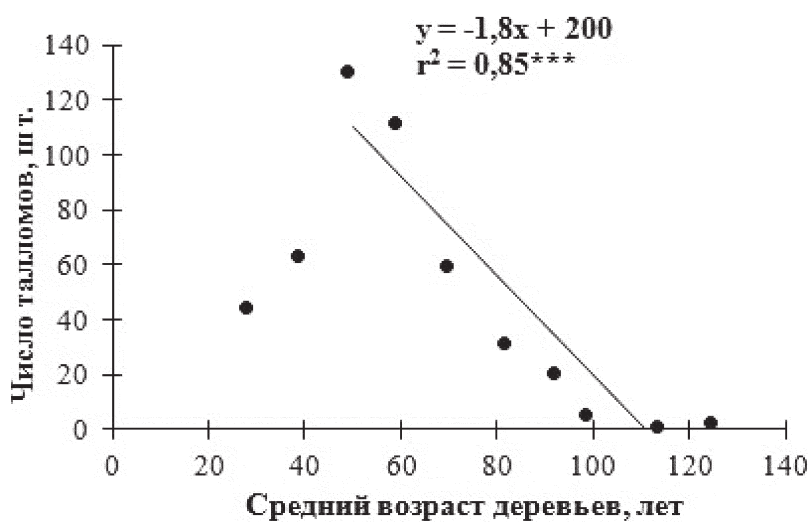

Рис. 5. Число талломов B. nadvornikiana на деревьях ели европейской разного возраста

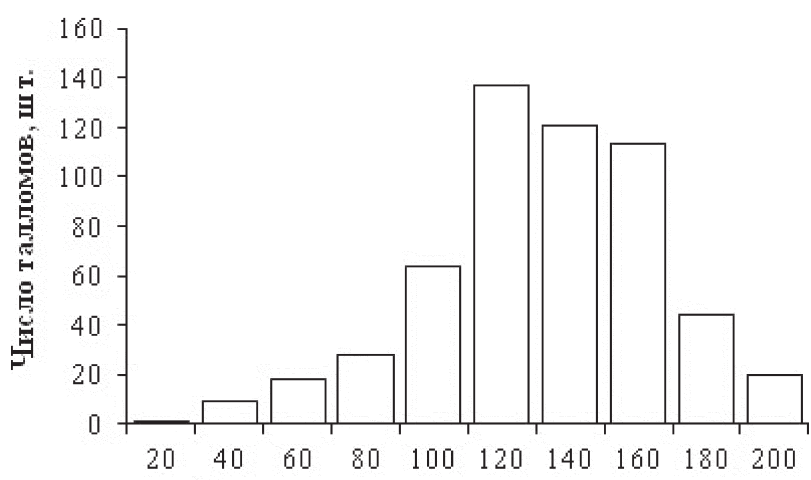

Высота пр опр астаншя над землей, $\mathrm{cm}$

Рис. 6. Число талломов B. nadvornikiana на различной высоте от поверхности земли

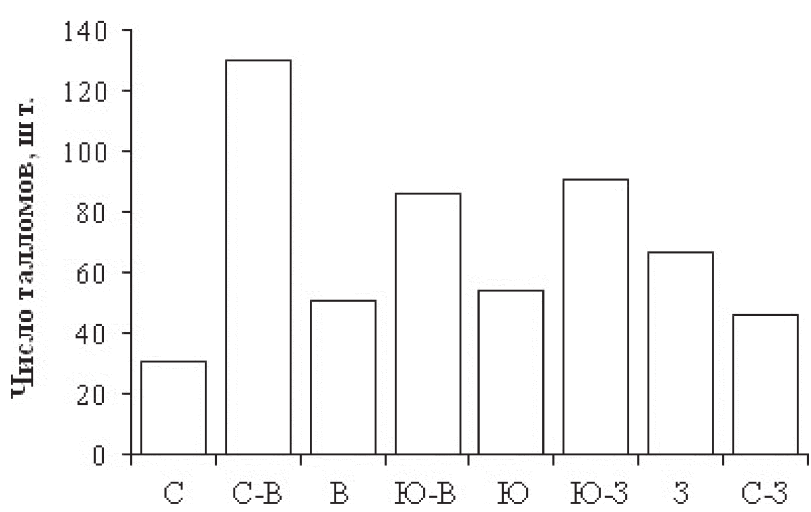

Рис. 7. Число талломов В. nadvornikiana на ветвях, ориентированных к разным сторонам света

с повышенной влажностью [Kuusinen, 1991; Голубкова, 1996]. Именно поэтому на более старых, высоких деревьях с большим диаметром ствола число талломов меньше по сравнению с молодыми.

Вид был обнаружен на ветвях на высоте от 16 до 200 см от земли. Финский исследователь М. Куусинен предположил, что B. nadvornikiana может быть обнаружена в верхней части кроны деревьев и поэтому ее обилие часто, как предполагает автор, оказывается заниженным или неучтенным [Kuusinen, 1991]. Однако в наших исследованиях при визуальном осмотре ветвей, расположенных выше по стволу, а также крон упавших деревьев (10 шт.), которые всегда, при наличии, тоже обследовались, талломов вида обнаружить не удалось. Максимальное число талломов (58 \%) было обнаружено на высоте 108-161 см. С увеличением высоты произрастания над землей число талломов первоначально увеличивается, за счет большей вероятности наличия субстрата, а после - снижается. Последнее связано с тем, что наиболее благоприятные для обитания бриории условия возникают в зоне нижней части ветвей, находящихся невысоко от земли, вероятно, ввиду более высокой влажности (рис. 6).

На территории ПетрГО вид произрастает на ветвях ели, ориентированных ко всем сторонам света. Наибольшее число талломов (38 \%) было выявлено на ветвях, ориентированных на северо-восток (рис. 7).

Для изучения динамики характеристик популяции бриории в ходе сукцессионной серии при восстановлении еловых лесов был составлен следующий ряд сообществ (табл. 2).

1. Молодые осиновые леса (возраст ели 2036 лет) (здесь и далее 2 ПП общей площадью 0,5 га). В данных лесах вид не был обнаружен, вероятно, ввиду молодого возраста ели.

2. Средневозрастные осинники с елью, которая выходит из стадии подроста (возраст ели 30-49 лет). В указанной группе насчитывается 104 таллома со средней длиной $43 \pm 1,4$ мм. В этом возрасте у ели появляются нижние ветви, лишенные хвои, и бриория активно их заселяет.

3. Смешанный елово-осиновый лес (возраст ели 49-93 года). В этой группе сообществ число талломов снижается до 14 (средняя длина $37 \pm 5,5)$ ввиду того, что на данной стадии сукцессии еще не формируется разновозрастное поколение ели, а увеличение высоты кроны у более взрослых елей приводит к уменьшению числа нижних ветвей - основного субстрата, пригодного для заселения вида.

4. Относительно разновозрастный ельник с единичными старыми осинами (возраст ели 20-125 лет). В четвертой группе сообществ число талломов вновь увеличивается до 119 , их длина составляет $43 \pm 1,9$. Это объясняется постепенным образованием разновозрастного древостоя ели в сообществе в ходе естественной динамики развития леса, что ведет к увеличению числа молодых деревьев с невысокой кроной.

Таким образом, изменение количественных показателей популяций бриории 
объясняется наличием подходящего субстрата (молодых елей с невысокой кроной), а также подходящих для произрастания условий (влажность, затененность).

Кроме того, было изучено состояние вида в ельниках, отличающихся по степени антропогенной нагрузки. При определении степени антропогенной нагрузки учитывалось местоположение пробной площади (близость к жилой застройке), степень рекреационной нагрузки, количество мертвой древесины (сухостоя, валежа, вывалов). Данные сообщества были выделены в три категории: сильнонарушенные, средненарушенные и относительно малонарушенные (табл. 2), согласно работе М. Н. Подгорной с соавторами [Подгорная и др., 2013]. Считается, что B. nadvornikiana является индикатором лесов высокой природоохранной ценности. Из литературы известно, что этот вид растет чаще всего в старовозрастных хвойных лесах и является их индикатором [Kuusinen, 1991; Boudreault et al., 2013]. В наших исследованиях бриория была обнаружена как в сильнонарушенных (6), так и в средненарушенных сообществах (143). При этом средняя длина таллома бриории в сильнонарушенных сообществах составляет $36 \pm 6,6$ мм, а на территории средненарушенных сообществ достигает $47 \pm 2,0$ мм. На территории относительно малонарушенных лесов число талломов составило 148, со средней длиной таллома $41 \pm$ 3,3 мм.

Существование вида в сильнонарушенных и средненарушенных лесах ПетрГО может свидетельствовать о том, что бриория Надворника в данных условиях не является строгим индикатором малонарушенных сообществ. Однако мы предполагаем, что простой регистрации факта присутствия/отсутствия этого вида недостаточно для такого заключения. Использование же количественных показателей (число талломов на единицу площади и его размеры) позволяет установить, что состояние популяции этого вида в сильнонарушенных сообществах значительно хуже, чем в средне- и относительно малонарушенных. Анализ реакции B. nadvornikiana на естественные и антропогенные факторы позволяет отнести ее к группе чувствительных. Хотя необходимо отметить, что анализ полученных результатов осложняется тем, что в городских условиях значительный вклад в фактор «антропогенное нарушение» вносит загрязнение воздушной среды.

\section{Заключение}

Состояние популяций В. nadvornikiana в условиях естественных растительных сообществ в границах ПетрГО можно охарактеризовать как нормальное. Вид на этой территории не является редким. Высокая встречаемость вида может быть вызвана несколькими причинами. С одной стороны, этому могут способствовать довольно мягкий климат южной Карелии, обусловленный близостью Белого и Балтийского морей, и наличие крупного водоема (Онежское озеро), оказывающего существенное влияние на мезоклимат ПетрГО. По литературным данным, вид чаще всего обитает в лесах вдоль берегов озер, рек, болот, а также встречается в еловых лесах с высокой влажностью [Голубкова, 1996; Boudreault et al., 2013]. С другой стороны, наличие на территории ПетрГО значительных по площади территорий с естественной растительностью и относительно невысокий уровень атмосферного загрязнения [Государственный доклад..., 2015] также могут быть причиной высокого обилия вида. Возможно, именно сохранившиеся в пределах ПетрГО участки еловых сообществ с относительно разновозрастным древостоем являются стабильной средой обитания бриории Надворника. Благодаря сохранению данных сообществ происходит расселение вида на другие территории, в том числе сильно- и средненарушенные, в которых появляется подходящий субстрат - нижние ветви елей. В настоящее время, по-видимому, городская среда не создает угрозу исчезновения данного вида из изученных сообществ. Однако вырубка лесных насаждений, относящихся к средне- и относительно малонарушенным сообществам, в будущем может способствовать сокращению численности вида на территории города. Хочется особо подчеркнуть, что изученные закономерности распространения и экологии бриории Надворника получены лишь для небольшой части среднетаежных лесных сообществ южной Карелии. Поэтому для принятия решения об исключении вида из Красной книги Республики Карелия необходимы исследования по всей территории республики, так как состояние и экология вида в разных географических районах могут существенно различаться ввиду разных условий окружающей среды, связанных как с естественными, так и с антропогенными факторами.

В целом, как показали исследования, наиболее информативным методом при изучении особенностей распространения вида B. nadvornikiana является метод пробных площадей, позволяющий более полно учитывать численность талломов, которые у этого вида в условиях городской среды часто могут иметь достаточно мелкие размеры. С другой стороны, маршрутный метод, хотя значительно уступает в точности, позволяет оценить 
общее распространение вида на изучаемой территории и его встречаемость в разных типах сообществ. Таким образом, совмещая эти два подхода, можно подойти к изучению экологии отдельных видов лишайников более комплексно.

Работа выполнена при поддержке Программы стратегического развития ПетрГУ в рамках реализации комплекса мероприятий по развитию научно-исследовательской деятельности на 2012-2016 гг.

\section{Литература}

Андросова В. И. Характеристика города Петрозаводска // Растения и лишайники города Петрозаводска (аннотированные списки видов). Петрозаводск: ПетрГУ, 2010. С. 8-12.

Волков А. Д. Типы леса Карелии. Петрозаводск: Карельский научный центр РАН, 2008. 180 с.

Голубкова Н. С. Определитель лишайников России. Том 6. Алекториевые, Пармелиевые, Стереокаулоновые. СПб.: Наука, 1996. 203 с.

Государственный доклад о состоянии окружающей среды Республики Карелия в 2014 г. Петрозаводск: Verso, 2015. 272 с.

Ивантер Э. В., Коросов А. В. Введение в количественную биологию. Петрозаводск: ПетрГУ, 2011. $304 \mathrm{c}$.

Красная книга Республики Карелия. Петрозаводск: Карелия, 2007. 368 с.

Красная книга природы Ленинградской области. Том 2. Растения и грибы. СПб.: Мир и семья, 2000. $676 \mathrm{c}$. $544 \mathrm{c}$

Красная книга Псковской области. Псков, 2014.

Красная книга Рязанской области. Изд. 2-е, перераб. и доп. Рязань: Голос губернии, 2011. 626 с.

Красная книга Республики Татарстан. Казань, 2006. 812 c.

\section{References}

Androsova V. I. Kharakteristika goroda Petrozavodska [Characteristics of the city of Petrozavodsk]. Rasteniya i lishainiki goroda Petrozavodska (annotirovannye spiski vidov) [Plants and lichens in the City of Petrozavodsk (annotated species checklists)]. Petrozavodsk: PetrGU, 2010. P. 8-12.

Volkov A. D. Tipy lesa Karelii [Forest types of Karelia]. Petrozavodsk: KarRC of RAS, 2008. 180 p.

Golubkova N. S. Opredelitel' lishainikov Rossii. T. 6. Alektorievye, Parmelievye, Stereokaulonovye [Guide for identification of lichens of Russia. Vol. 6. Alectoriaceae, Parmcliaccau, Stereocaulaceae]. St. Petersburg: Nauka, 1996. 203 p.

Gosudarstvennyi doklad o sostoyanii okruzhayushchei sredy Respubliki Kareliya v 2014 g. [State report on the status of the environment of Republic of Karelia in 2014]. Petrozavodsk: Verso, 2015. 272 p.
Подгорная М. Н., Тарасова В. Н., Марковская Н. В., Марковская Е. Ф. Ценные лесные территории Петрозаводского городского округа // Принципы экологии. 2013. № 1. С. 51-61.

Фадеева М. А., Голубкова Н. С., Витикайнен О., Ахти T. Конспект лишайников и лихенофильных грибов Республики Карелия. Петрозаводск: Карельский научный центр РАН, 2007. 194 с.

Boudreault C., Coxson D. S., Bergeron Y. et al. Do forests treated by partial cutting provide growth conditions similar to old-growth forests for epiphytic lichens? // Biological Conservation. Vol. 159. 2013. P. 458-467.

Gärdenfors U. (ed.). Rödlistade arter i Sverige 2010 Uppsala: ArtDatabanken, SLU, 2010. 592 p.

Kuusinen M. Bryoria nadvornikiana in Finland // Graphis Scripta. 1991. Vol. 4, no. 2. P. 78-80.

Rassi P., Hyvärinen E., Juslén A., Mannerkoski I. (Toim.). Suomen lajien uhanalaisuus - Punainen kirja 2010. Helsinki: Ympäristöministeriö \& Suomen ympäristökeskus, 2010. 685 s.

Signalarter: indikatorer på skyddsvärd skog: flora över kryptogamer / Ed. By J. Nitare. Skogsstyrelsen forlag, 2000. $384 \mathrm{~s}$.

Tarasova V. N., Sonina A. V., Androsova V. I., Ahti T. The present lichen flora of the city of Petrozavodsk // Folia Cryptog. Estonica. 2013. Vol. 50. P. 57-66.

Tarasova V. N., Sonina A. V., Androsova V. I., Ahti T. The lichens from the City of Petrozavodsk in the Herbarium of the Botanical Museum, University of Helsinki $(\mathrm{H})$ // Folia Cryptogamica Estonica. 2015. Vol. 52. P. 41-50.

Thell A., Moberg R. (eds). Nordic Lichen Flora. Parmeliaceae. Uppsala University \& Nordic Lichen Society, Uppsala, 2011. Vol. 4. 184 p.

Timdal E., Bratli H., Haugan R. et al. Lichens. In The 2010 Norwegian Red List for Species. Trondheim: Norwegian Biodiversity Information Centre, 2010. P. $125-137$.

Wang L. S., Harada H., Koh Y. J., Hur J. S. Two species of Bryoria (Lichenized Ascomycota, Parmeliaceae) from the Sino-Himalayas // Mycobiology. 2005. Vol. 33, no. 4. P. 173-177. doi: 10.4489/MYCO.2005.33.4.173

Поступила в редакцию 11.04.2015

Ivanter E. V., Korosov A. V. Vvedenie v kolichestvennuyu biologiyu [Introduction to quantitative biology]. Petrozavodsk: PetrGU, 2011. 304 p.

Krasnaya kniga Respubliki Kareliya [Red Data Book of the Republic of Karelia]. Petrozavodsk: Kareliya, 2007. $368 \mathrm{p}$

Krasnaya kniga prirody Leningradskoi oblasti. T. 2. Rasteniya i griby [Red Data Book of Nature of the Leningrad Region. Vol. 2. Plants and fungi]. St. Petersburg, 2000. 676 p.

Krasnaya kniga Pskovskoi oblasti [Red Data Book of the Pskov region]. Pskov, 2014. 544 p.

Krasnaya kniga Ryazanskoi oblasti. Izd. 2-e, pererab. i dop. [Red Data Book of the Ryazan Region $2^{\text {nd }}$ ed., rev. and enl.]. Ryazan', 2011. 626 p.

Krasnaya kniga Respubliki Tatarstan [Red Data Book of the Republic of Tatarstan]. Kazan', 2006. 812 p. 
Podgornaya M. N., Tarasova V. N., Markovskaya N. V., Markovskaya E. F. Tsennye lesnye territorii Petrozavodskogo gorodskogo okruga [Valuable forest territoreis of Petrozavodsk municipal district]. Printsipy ekologii. 2013. No. 1. P. 51-61.

Fadeeva M. A., Golubkova N. S., Vitikainen O., Akhti T. Konspekt lishainikov i likhenofil'nykh gribov Respubliki Kareliya [Synopsis of lichens and lichenicolous fungi of the Republic of Karelia]. Petrozavodsk: KarRC of RAS, 2007. 194 p.

Boudreault C., Coxson D. S., Bergeron Y., Stevenson S., Bouchard M. Do forests treated by partial cutting provide growth conditions similar to old-growth forests for epiphytic lichens? Biological Conservation. Vol. 159. 2013. P. 458-467.

Gärdenfors U. (ed.). Rödlistade arter i Sverige 2010. Uppsala: ArtDatabanken, SLU, 2010. 592 p.

Kuusinen M. Bryoria nadvornikiana in Finland. Graphis Scripta. 1991. Vol. 4, no. 2. P. 78-80.

Rassi P., Hyvärinen E., Juslén A., Mannerkoski I. (Toim.). Suomen lajien uhanalaisuus - Punainen kirja 2010. Helsinki: Ympäristöministeriö \& Suomen ympäristökeskus, 2010. $685 \mathrm{~s}$

\section{СВЕДЕНИЯ ОБ АВТОРАХ:}

\section{Фенько Анна Анатольевна}

аспирант

Институт биологии Карельского научного центра РАН

ул. Пушкинская, 11, Петрозаводск, Республика Карелия, Россия, 185910

эл. почта: angelina911@ya.ru

тел.: (8142) 762712

\section{Тарасова Виктория Николаевна}

доцент кафедры ботаники и физиологии растений, к. б. н. Петрозаводский государственный университет, эколого-биологический факультет

пр. Ленина, 33, Петрозаводск, Республика Карелия, Россия, 185910

эл. почта: vika18@sampo.ru

тел.: (8142) 711019
Signalarter: indikatorer på skyddsvärd skog: flora över kryptogamer. Ed. By J. Nitare. Skogsstyrelsen forlag, 2000. 384 s.

Tarasova V. N., Sonina A. V., Androsova V. I., Ahti T. The present lichen flora of the city of Petrozavodsk. Folia Cryptog. Estonica. 2013. Vol. 50. P. 57-66.

Tarasova V. N., Sonina A. V., Androsova V. I., Ahti T. The lichens from the City of Petrozavodsk in the Herbarium of the Botanical Museum, University of Helsinki $(\mathrm{H})$. Folia Cryptogamica Estonica. 2015. Vol. 52. P. 41-50.

Thell A., Moberg R. (eds). Nordic Lichen Flora. Parmeliaceae. Uppsala University \& Nordic Lichen Society, Uppsala, 2011. Vol. 4. 184 p.

Timdal E., Bratli H., Haugan R., Holien H., Tønsberg T. Lichens. In The 2010 Norwegian Red List for Species. Trondheim: Norwegian Biodiversity Information Centre, 2010. P. 125-137.

Wang L. S., Harada H., Koh Y. J., Hur J. S. Two species of Bryoria (Lichenized Ascomycota, Parmeliaceae) from the Sino-Himalayas. Mycobiology. 2005. Vol. 33, no. 4. P. 173-177. doi: 10.4489/MYCO. 2005.33.4.173

Received April 11, 2015

\section{CONTRIBUTORS:}

\section{Fenko, Anna}

Institute of Biology, Karelian Research Centre,

Russian Academy of Sciences

11 Pushkinskaya St., 185910 Petrozavodsk, Karelia, Russia e-mail: angelina911@ya.ru

tel.: (8142) 762712

\section{Tarasova, Viktoriya}

Petrozavodsk State University

33 Lenin St., 185910 Petrozavodsk, Karelia, Russia

e-mail: vika18@sampo.ru

tel.: (8142) 711019 